\title{
Induced Production of Acidic Polysaccharide by Benzalkonium Chloride-resistant Bacterium (Enterobacter species) in the Presence of Hexachlorophen and Chlorhexidine
}

\author{
Kazuaki NishIKAWA* and Susumu OI \\ Faculty of Science, Osaka City University, Sugimoto-cho, \\ Sumiyoshi-ku, Osaka 558, Japan \\ * Nagayoshi Osaka Public High School, Nagayoshinagahara, \\ Hirano-ku, Osaka 547, Japan
}

Received April 30, 1986

\begin{abstract}
The bacterium, which was isolated from soil and identified as Enterobacter sp., was induced by hexachlorophen (HCP) and chlorhexidine $(\mathrm{CH})$, as well as benzalkonium chloride (BC), to produce acidic polysaccharide. $\mathrm{HCP}$ is a bisphenol and $\mathrm{CH}$ is a bisbiguanido, while $\mathrm{BC}$ is a quarternary ammonium compound. The cells produced the maximum amount of the polysaccharide $(0.3 \sim 0.9 \mathrm{mg}$ as total sugar/mg dry weight cells) in a $0.07 \mathrm{M}$ potassium phosphate buffer $(\mathrm{pH} 7.2)$ containing $0.22 \mathrm{M}$ glucose and approximately $0.1 \mathrm{~mm} \mathrm{BC}$ or $\mathrm{HCP}$, or $0.06 \mathrm{~mm} \mathrm{CH}$. There was no growth of the cells in these conditions. The polysaccharides produced in the presence of each drug were all composed of fucose, glucose, galactose and glucuronic acid. At the optimum concentration for polysaccharide production, a large amount of UV-absorbing material was released from the cells.
\end{abstract}

Benzalkonium chloride (alkylbenzyltrimethylammoniumchloride, $\mathrm{BC}$ ) is a cationic detergent of the quarternary ammonium compound, widely used as an antiseptic. The first step of its antibacterial action is believed to be adsorption onto the bacterial surface and reaction with lipid and protein complexes of the cytoplasmic membrane. ${ }^{1)}$ Hotchkiss ${ }^{2}$ proved that nitrogen- and phosphorus-containing compounds leaked from staphylococci treated with a quarternary ammonium compound or tyrocidin. Salton ${ }^{3)}$ studied leakage from cells of Staphylococcus aureus after treatment with cetyltrimethylammonium bromide, using absorbancy at $260 \mathrm{~nm}$ as a convenient method for assessing the extent of leakage.

A bacterium resistant to $\mathrm{BC}$ was isolated from soil and identified as Enterobacter species. ${ }^{4}$ When the bacterium was cultivated in a liquid medium containing $\mathrm{BC}$, the cells adsorbed BC and produced a large amount of an acidic polysaccharide (APS) $)^{5}$. APS was composed of glucose, galactose, fucose, glucuronic acid, acetic acid and pyruvic acid. It was similar to colanic acid of E. coli reported by Goebel ${ }^{6)}$ and Sutherland. ${ }^{7,8)}$ The bacterium produced little APS in the absence of $\mathrm{BC}$, while the addition of $\mathrm{BC}$ to the culture media resulted in the production of APS. Kang and Markovitz ${ }^{9}$ reported the induction of capsular polysaccharide synthesis by $p$-fluorophenylalanine (FPA) in E. coli. They presumed that FPA was incorporated into the protein product of the $R_{1}$ gene (repressor) and altered it sufficiently to allow derepression of several enzymes which synthesized the polysaccharide. The APS production of the bacterium was also induced by FPA. This fact indicated that the APS production of the bacterium was also controlled by a regulatory gene, and derepressed by inactivation of the repressor protein. However, it seems impossible that $\mathrm{BC}$ could have been incorporated into the repressor protein, altering it to an inactive form, since $\mathrm{BC}$ is dif- 
ferent from FPA in chemical property and structure.

The authors investigated other compounds which have the same effect on the bacterium as $\mathrm{BC}$ in order to approach the mechanism of the induced production of APS by BC. Hexachlorophene (2,2-methylenebis-(3,4,6trichlorophenol); HCP), Chlorhexidine (1,6di(4-chlorophenyldiguanido)hexane; $\mathrm{CH}$ ) and polymixin were found to cause the production of APS. The present paper describes the effect of $\mathrm{HCP}, \mathrm{CH}$ and $\mathrm{BC}$ on the bacterium.

\section{MATERIALS AND METHODS}

The bacterium and its culture. The $\mathrm{BC}$ resistant bacterium identified as Enterobacter species was used. The bacterium was grown in Davis' minimal medium which contained $1 \%$ glycerol instead of glucose, $0.25 \mathrm{~mm} \mathrm{CaCl}_{2}$ and $10 \mu \mathrm{g} / \mathrm{ml}$ thiamine $-\mathrm{HCl}$ on a reciprocal shaker $(120$ rpm) at $30^{\circ} \mathrm{C}$.

Preparation of the cell suspensions. Suspensions were prepared with cells from the late exponential phase of growth. Cells were harvested by centrifugation, washed with $0.07 \mathrm{M}$ potassium phosphate buffer $(\mathrm{pH} 7.2)$ and suspended in the same buffer $(1.0 \mathrm{mg}$ of dry weight cells/ $\mathrm{ml})$.

Production and isolation of APS. Nine milliliters of cell suspension were added to test-tubes containing 40 mg glucose and each drug in $1 \mathrm{ml}$ of distilled water. The suspension was incubated on a reciprocal shaker (120 $\mathrm{rpm}$ ) for $48 \mathrm{hr}$ at $30^{\circ} \mathrm{C}$. Cells were removed by centrifugation and two volumes of acetone was added to the supernatant. After leaving for $18 \mathrm{hr}$ at room temperature, the resulting precipitate was collected and washed with $67 \%$ acetone and dissolved in distilled water (crude solution of APS). The total sugar content of the precipitate was determined by the phenol-sulfuric acid method. ${ }^{10)}$

Release and estimation of $U V$-absorbing material. Nine milliliters of cell suspension were added to test-tubes containing each drug, or none as a control, in $1 \mathrm{ml}$ distilled water. The suspension was incubated on a reciprocal shaker $(120 \mathrm{rpm})$ for $3 \mathrm{hr}$ at $30^{\circ} \mathrm{C}$. The extent of leakage was assessed by measuring the absorbancy at 260 $\mathrm{nm}$ of the supernatant in a Shimadzu model UV-200 spectrophotometer equipped with $1-\mathrm{cm}$ light-path quartz cuvettes.

Estimation of the bacteriostatic effect of each drug. Inhibition by the drugs was tested in test-tubes containing increasing concentrations of each drug in Davis' minimal medium, modified as mentioned above. Each tube was inoculated with approximately $2.2 \times 10^{7}$ cells and incubated for $48 \mathrm{hr}$ at $30^{\circ} \mathrm{C}$. The lowest concentration of drug that completely inhibited visible growth was recorded.

TLC of sugar components of APS. A sample of APS (10 mg) was hydrolyzed in $5 \mathrm{ml}$ of $1 \mathrm{~N} \mathrm{H}_{2} \mathrm{SO}_{4}$ at $85^{\circ} \mathrm{C}$ for $4 \mathrm{hr}$. The hydrolysate was neutralized with $\mathrm{BaCO}_{3}$ and the supernatant was concentrated to $1 \mathrm{ml}$. Five microliters of the concentrated solution was chromatographed on a Silica Gel G plate. The plate was developed with a mixture of ethylacetate, pyridine, acetic acid and water $(5: 5: 1: 3)$ at room temperature. The developed plate was dipped once in $10 \% \mathrm{H}_{2} \mathrm{SO}_{4}$ (in ethanol) and heated gently.

\section{RESULTS}

\section{Effect of various compounds on APS produc- tion}

There was no inductive effect of $\mathrm{CuSO}_{4}$, $\mathrm{HgCl}_{2}$, fuchsin and crystalviolet on the APS production of the cell. These compounds contain positive charges in the molecules, as does BC. Ethanol and phenol, which act on the membrane permiability of the cells, and penicillin and streptomycin, which inhibit growth of the bacterium, also caused no production of APS. The addition of $\mathrm{HCP}, \mathrm{CH}$ and polymyxin, as well as of $\mathrm{BC}$, resulted in the production of APS. Though these compounds or antibiotics are different from one another in chemical structure, they share a similar characteristic property, i.e., they are surface-active antibacterials.

\section{Induced production of $A P S$ by $B C, H C P$ and $\mathrm{CH}$}

The APS production of the cells was examined in a $0.07 \mathrm{M}$ phosphate buffer ( $\mathrm{pH} 7.2)$ containing $0.22 \mathrm{M}$ glucose and $0.1 \mathrm{~mm} \mathrm{BC}$. Production occurred exponentially and reached maximum at about $48 \mathrm{hr}(0.9 \mathrm{mg}$ as total sugar $/ \mathrm{ml}$ ), as shown in Fig. 1.

The optimum concentrations of $\mathrm{BC}$ and $\mathrm{HCP}$ were in the same range of $0.1 \mathrm{mM}$, while that of $\mathrm{CH}$ was a little lower than this range i.e., $0.06 \mathrm{~mm}$, as shown in Table II. The maximum amounts of APS produced in the pres- 
ence of HCP were as much as in the presence of $\mathrm{BC}$, while the amounts in the case of $\mathrm{CH}$ were smaller. Differences in the effects

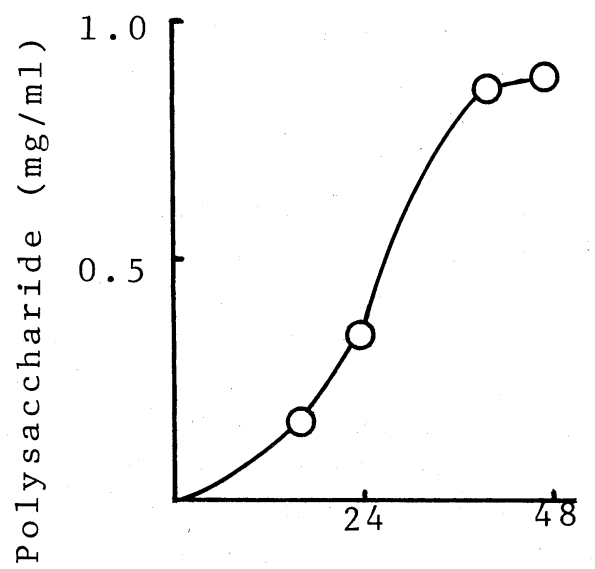

Incubation time, hr

FIG. 1. Time Course of Polysaccharide Production by Cells in $0.07 \mathrm{M}$ Potassium Phosphate Buffer with $0.1 \mathrm{~mm}$ BC.

Table I. EFFect of Various Concentrations of BC, HCP AND CH ON GROWTH OF THE BACTERIUM

\begin{tabular}{lccc}
\hline & \multicolumn{3}{c}{ Compound } \\
\cline { 2 - 4 } Conc. (mM) & BC & HCP & CH \\
\hline 0.1 & - & - & - \\
0.03 & - & - & - \\
0.01 & + & + & - \\
0.003 & + & + & + \\
\hline
\end{tabular}

Tested in Davis' minimal medium for $48 \mathrm{hr}$ at $30^{\circ} \mathrm{C}$.

+ , growth; -, no growth. on APS production between $\mathrm{BC}$ and $\mathrm{CH}$ may be attributed to the inhibitory action of $\mathrm{CH}$ on the bacterial growth, as shown in Table I.

\section{Release of UV-absorbing material from cells of the bacterium}

When cells were treated with $0.1 \mathrm{~mm} \mathrm{BC}$ in a $0.07 \mathrm{M}$ potassium phosphate buffer, a considerable amount of UV-absorbing material was released. The release began at the moment when the $\mathrm{BC}$ was added to the cell suspension, and it increased gradually to reach the maximum after about $4 \mathrm{hr}$ of incubation, as shown in Fig. 2. In the case of $\mathrm{HCP}$, the maximum amount of the release was slightly larger than in the case of $\mathrm{BC}$, though the start of the release was observed a little later. On the other hand, $\mathrm{CH}$ had a immediate effects on the release. The optimum concentrations of $\mathrm{BC}$ and HCP were in the similar range of $0.1 \mathrm{~mm}$, while that of $\mathrm{CH}$ was $0.06 \mathrm{~mm}$, as shown in Table II. These optimum concentrations approximately corresponded with the optimum concentrations for the production of APS. At higher concentrations of each drug, cells coagulated and the release was decreased.

\section{Properties and sugar composition of APS}

APS produced in the presence of BC, HCP or $\mathrm{CH}$ formed white and fibrous precipitates with the addition of acetone at the final con-

Table II. Effect of Various Concentrations of BC, HCP and CH on Polysaccharide Production by Cells and Release of UV-Absorbing Material from Cells

\begin{tabular}{|c|c|c|c|c|c|c|}
\hline \multirow[b]{2}{*}{$\begin{array}{l}\text { Conc. } \\
\text { (mM) }\end{array}$} & \multicolumn{2}{|r|}{$\mathrm{BC}$} & \multicolumn{2}{|c|}{$\mathrm{HCP}$} & \multicolumn{2}{|c|}{$\mathrm{CH}$} \\
\hline & $\begin{array}{c}\text { O.D. }^{a} \\
\text { at } 260 \mathrm{~nm}\end{array}$ & $\begin{array}{c}\text { Acidic }^{b} \\
\text { polysaccharide } \\
(\mu \mathrm{g} / \mathrm{ml})\end{array}$ & $\begin{array}{c}\text { O.D. }^{a} \\
\text { at } 260 \mathrm{~nm}\end{array}$ & $\begin{array}{c}\text { Acidic }^{b} \\
\text { polysaccharide } \\
(\mu \mathrm{g} / \mathrm{ml})\end{array}$ & $\begin{array}{l}\text { O.D. }{ }^{a} \\
\text { at } 260 \mathrm{~nm}\end{array}$ & $\begin{array}{c}\text { Acidic }^{b} \\
\text { polysaccharide } \\
(\mu \mathrm{g} / \mathrm{ml})\end{array}$ \\
\hline 0 & 0.3 & 22 & 0.3 & 22 & 0.3 & 22 \\
\hline 0.03 & 0.68 & 11 & 0.66 & 11 & 0.60 & 34 \\
\hline 0.06 & 1.20 & 34 & 1.32 & 492 & 1.80 & 346 \\
\hline 0.1 & 1.74 & 882 & 1.90 & 916 & 1.20 & 45 \\
\hline 0.3 & 1.74 & 369 & 0.60 & 56 & 1 & 1 \\
\hline
\end{tabular}

a Incubated in $0.07 \mathrm{M}$ potassium phosphate buffer (pH 7.2) for $3 \mathrm{hr}$ at $30^{\circ} \mathrm{C}$.

${ }^{b}$ Incubated in $0.07 \mathrm{M}$ potassium phosphate buffer ( $\mathrm{pH} 7.2$ ) containing $0.22 \mathrm{M}$ glucose for $48 \mathrm{hr}$ at $30^{\circ} \mathrm{C}$. Expressed as total sugar per milliliter of cell suspension. 


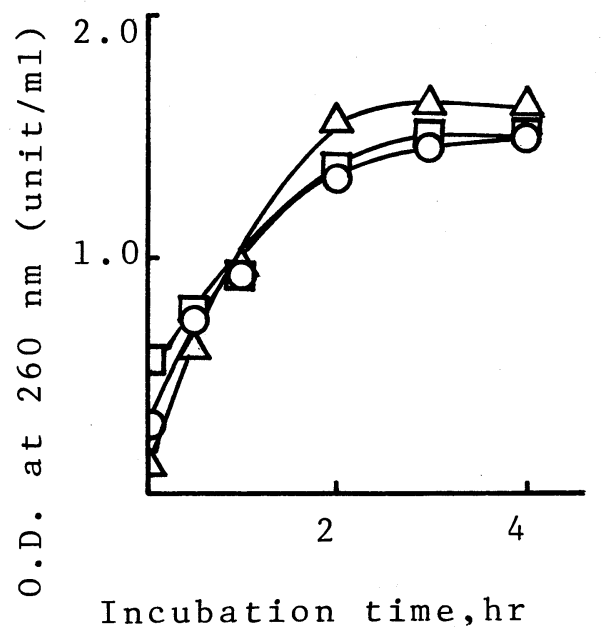

FIG. 2. Release of UV-absorbing Material from Cells Treated with $\mathrm{BC}, \mathrm{HCP}$ or $\mathrm{CH}$.

$-\mathrm{O}-, \mathrm{BC} ;-\triangle-, \mathrm{HCP} ;-\square-, \mathrm{CH}$. The curves are corrected for control leakage.

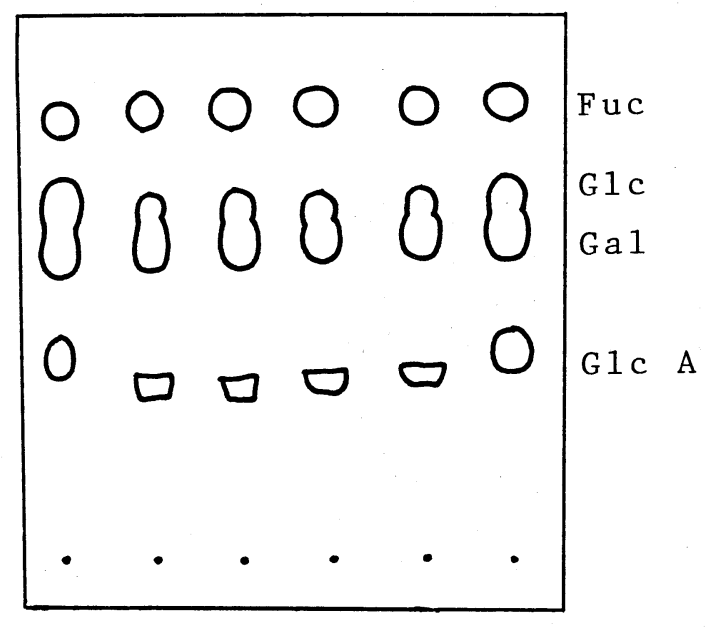

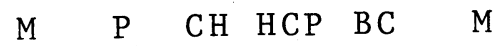

Fig. 3. TLC of Sugar Components of APS Produced in the Presence of BC, HCP, $\mathrm{CH}$ and Polymyxin (P).

Fuc, fucose; Glc, glucose; Gal, galactose; Glc A, glucuronic acid; M, marker (Fuc, Glc, Gal, and Glc A).

centration of $67 \%$. When these precipitates were dissolved in distilled water at the final concentration of $0.1 \%$, solutions of each polysaccharide were viscous and showed acidic $\mathrm{pH}$.

The results of ascending TLC using the solvent composed of ethylacetate, pyridine, acetic acid and water $(5: 5: 1: 3)$ showed that the APSs was all composed of fucose, glucose, galactose and glucuronic acid, as shown in Fig. 3. Thus it was assumed that the chemical composition of the APSs produced in the presence of each drug were the same.

\section{DISCUSSION}

Among examined compounds $\mathrm{HCP}, \mathrm{CH}$ and polymyxin could cause the bacterium to produce APS as well as BC. Trimethylbenzylammonium chloride and tetramethylammonium chloride ${ }^{5}$ containing quarternary ammonium, metal ion such as $\mathrm{Cu}^{2+}$ and basic dyes such as fuchsin had no inductive effect on the APS production of the bacterium, though they are considered to have been adsorbed on negatively charged bacterial surface. Anionic detergents such as SLS $^{5)}$ also had no inductive effect. Anionic detergents are generally less toxic to bacteria than cationic detergents although their target is also the cytoplasmic membrane. This may be due to the fact that in SDS and other anionic detergents the active ion is negatively charged and may be repelled by the negatively charged bacterial surface. ${ }^{1)}$ However, HCP, which is a weak anion, had an inductive effect on the APS production of the bacterium. On the other hand, $\mathrm{CH}$ and polymyxin are cationic detergents as well as $\mathrm{BC}$, but molecules of $\mathrm{CH}$ and polymyxin do not have ammonium-alkyl moiety which those of BC have. Thus, the four compounds are different from each other in chemical structure and property. However, these compounds had a common characteristic action on the bacterium in that they caused the release of UV-absorbing material from the cytoplasm. When each detergent was added to a cell suspension of the bacterium, UV-absorbing material was immediately released from the cells, with this release reaching its maximum in about $4 \mathrm{hr}$. At this time, the bacteria were not dead but started to produce APS. Vigorous production of APS occurred at the concentration of each drug optimum for release. Thus, the start of the APS production of the bacterium may 
be based on the release of UV-absorbing material from the cell.

The release of the UV-absorbing material from cells of the bacterium was not a fatal process because cells could produce APS after the maximum release occurred. Gerhardt ${ }^{11)}$ reported that the minimal lethal concentration of HCP to B. megaterium $(10 \mu \mathrm{g} / \mathrm{mg}$ of cell dry weight) caused comparatively. little leakage and that leakage of even a relatively great amount of intracellular material did not appear to be a primary cause of killing. In the case of $\mathrm{CH}$, arrest of growth of $E$. coli occurring at the concentration of $1.2 \mu \mathrm{g} / \mathrm{ml}$ was associated with a slight leakage of cellular constituents. ${ }^{12)}$ Longworth $^{13)}$ proposed the model that in the action of $\mathrm{CH}$, bacteriostasis can be induced by slight membrane damage and enzyme inhibition but bactericidal activity is attributable to precipitation of intracellular macromolecules. Hugo ${ }^{14)}$ pointed out that it is unlikely that leakage in itself is a rapid fatal process since this type of damage is often reparable. Cells of the bacterium could grow at the optimum concentration of each drug for the release of UV-absorbing material when a nitrogen source, e.g., ammonium sulfate, was added to the cell suspension containing glucose and each drug, but they produced little APS. At higher concentrations of each drug, cells coagulated and did not grow. A characteristic property of the bacterium is that the growth and the APS production of the bacterium are not inhibited by the release of a considerable amount of UV-absorbing material.

\section{REFERENCES}

1) A. B. Russell, W. B. Hugo and GAJ. Ayliffe, "Principles and Practice of Disinfection, Preservation and Sterilization," Academic Press Inc., London, 1982, p. 158.

2) R. D. Hotchkiss, Adv. Enzymol., 4, 153 (1944).

3) M. R. J. Salton, J. Gen. Physiol., 52, 227 (1968).

4) K. Nishikawa, S. Oi and T. Yamamoto, Agric. Biol. Chem., 43, 2473 (1979).

5) K. Nishikawa, S. Oi and T. Yamamoto, Agric. Biol. Chem., 43, 2305 (1979).

6) W. F. Goebel, Proc. Natl. Acad. Sci. U.S.A., 49, 464 (1963).

7) I. W. Sutherland, Biochem. J., 115, 935 (1969).

8) C. J. Lawson, C. W. McCleary, H. I. Nakada, D. A. Rees, I. W. Sutherland and J. F. Wilkinson, Biochem. J., 115, 947 (1969).

9) S. Kang and A. Markovitz, J. Bacteriol., 93, 584 (1967).

10) M. Dubois, K. A. Guilles, J. K. Hamilton, P. A. Rebers and F. Smith, Anal. Chem., 28, 350 (1956).

11) H. L. Joswick, Thomas, R. Corner, J. N. Silvernale and P. Gerhardt, J. Bacteriol., 108, 492 (1971).

12) W. B. Hugo and A. R. Longworth, J. Pharm. Pharmacol., 16, 655 (1964).

13) A. R. Longworth, "Inhibition and Destruction of the Microbial Cell," ed. by W. B. Hugo, Academic Press Inc., London, 1971, p. 95.

14) W. B. Hugo, J. Appl. Bacteriol., 30, 17 (1967). 